\title{
Trwałość warsztatu pracy producenta rolnego jako cel wsparcia w ramach wybranych działań Programu Rozwoju Obszarów Wiejskich 2014-2020
}

1. Rolnictwo jest w oczywisty sposób powiązane ze stanem i przekształceniami środowiska przyrodniczego, a jednocześnie decyduje o sytuacji gospodarczej znacznej części obszarów wiejskich. Ponadto jest szczególnie narażone na skutki niestabilności pogodowej ${ }^{1}$. Warunki działalności rolniczej powodują, że skala ryzyka w rolnictwie jest dużo większa niż w innych działach gospodarki i pozostaje w ścisłym związku ze zmianami klimatyczno-pogodowymi oraz możliwością wystąpienia chorób ${ }^{2}$. Ryzyko wiąże się z niepewnością i nieprzewidywalnością. Tematyka ryzyka produkcyjnego w rolnictwie jest podejmowana zarówno przez prawników, jak i ekonomistów ${ }^{3}$. Działalność rolnicza podlega oddziaływaniu czynników zewnętrznych, na które rolnicy mają ograniczony wpływ. Choć ryzyka nie

* Wydział Prawa i Administracji, Uniwersytet Warmińsko-Mazurski w Olsztynie.

1 I. Jędrzejczyk, Identyfikacja ryzyka na potrzeby ochrony ubezpieczeniowej sektora rolnego, „Rozprawy Ubezpieczeniowe” 2008, nr 4, s. 24.

${ }^{2}$ E. Kremer, Ubezpieczenia majątkowe rodzinnych gospodarstw rolnych, w: P. Litwiniuk (red.), Prawne mechanizmy wspierania i ochrony rolnictwa rodzinnego w Polsce i innych państwach Unii Europejskiej, Warszawa 2015, s. 377.

${ }^{3}$ R. Budzinowski, Przyrodniczo-techniczny czynnik rozwoju prawa rolnego, „Przegląd Prawa Rolnego" 2006, nr 1; I. Lipińska, Prawne aspekty zarządzania ryzykiem w działalności rolniczej, Warszawa 2019; B. Jeżyńska, Producent rolny jako przedsiębiorca, Lublin 2008; W. Rembisz, Kwestie ryzyka, cen, rynku, interwencji i stabilności dochodów w rolnictwie, Warszawa 2013. 
da się uniknąć, to producent rolny może przyjmować wobec niego różne postawy, których celem jest minimalizowanie negatywnych skutków pojawiających się zdarzeń, m.in. przez stosowanie określonych instrumentów wsparcia, zarówno krajowego, jak i unijnego.

Spośród wielu działań PROW 2014-2020 na uwagę zasługują „Inwestycje mające na celu ochronę wód przed zanieczyszczeniem azotanami pochodzącymi ze źródeł rolniczych”, „Wsparcie inwestycji w środki zapobiegawcze, których celem jest ograniczenie skutków prawdopodobnych klęsk żywiołowych, niekorzystnych zjawisk klimatycznych i katastrof" oraz „Przywracanie potencjału produkcji rolnej zniszczonego w wyniku wystąpienia klęsk żywiołowych"5. Działania te mają wspierać producentów rolnych zagrożonych lub dotkniętych szkodami spowodowanymi przez zdarzenia losowe i klęski żywiołowe, takie jak zanieczyszczenie wód przez azotany pochodzenia rolniczego, afrykański pomór świń, podtopienia upraw rolniczych. Kwestie te były przedmiotem badań nielicznych autorów, w tym Izabeli Lipińskiej ${ }^{6}$, ale nie doczekały się jeszcze szerszej analizy.

Za podjęciem tej tematyki przemawiają głównie względy społeczno-gospodarcze. Analizowane rozwiązania prawne dotyczące wsparcia inwestycji zapobiegających zniszczeniu oraz przywracających potencjał produkcji rolnej w ramach PROW 2014-2020 umożliwiają stabilizację i ochronę dochodów działalności rolniczej oraz przyczyniają się do trwałości gospodarowania ${ }^{7}$. Wsparcie oferowane rolnikom ma wymiar społeczny, gdyż w pro-

${ }^{4}$ PROW 2014-2020 został opracowywany na podstawie przepisów Unii Europejskiej, w szczególności rozporządzenia Parlamentu Europejskiego i Rady (UE) nr 1305/2013 z 17 grudnia 2013 r. w sprawie wsparcia rozwoju obszarów wiejskich przez Europejski Fundusz Rolny na rzecz Rozwoju Obszarów Wiejskich (EFRROW) i uchylającego rozporządzenie Rady (WE) nr 1698/2005 (Dz. Urz. UE L 347, s. 487) oraz aktów delegowanych i wykonawczych Komisji Europejskiej. Zob. E. Tomkiewicz, M. Bocheński, Polityka rozwoju obszarów wiejskich w perspektywie lat 2014-2020 w kontekście nowych wyzwań, „Studia Iuridica Agraria” 2012, t. X, s. 239.

${ }^{5}$ PROW 2014-2020 realizowany jest przez 14 działań, 35 poddziałań oraz 42 typy operacji. Ustawa z 20 lutego 2015 r. o wspieraniu rozwoju obszarów wiejskich z udziałem Europejskiego Funduszu Rolnego na rzecz Rozwoju Obszarów Wiejskich w ramach Programu Rozwoju Obszarów Wiejskich na lata 2014-2020 (Dz. U. 2017, poz. 562 ze zm.). Zob. J. Stoksik, Projektowanie pomocy unijnej w dziedzinie polityki rozwoju obszarów wiejskich, „Studia Iuridica Agraria” 2013, t. XI, s. 100, www.minrol.gov.pl [dostęp: 31.03.2020]; K. Giemza, Kształtowanie się wspótczesnego modelu europejskiego rolnictwa a kwestia agrarna, w: P. Litwiniuk (red.), Kwestia agrarna. Zagadnienia prawne i ekonomiczne, Warszawa 2016, s. 303-316. Por. A. Kuś, Rodzaje kompetencji Unii Europejskiej a unijna polityka podatkowa, „Studia z Polityki Publicznej” 2014, nr 2, s. 87;

E. Tomkiewicz, M. Bocheński, Polityka rozwoju..., s. 240.

${ }^{6}$ I. Lipińska, Prawne aspekty..., s. 378-385.

7 PROW 2014-2020 odpowiada misji i celom Wspólnej Polityki Rolnej. Zob. A. Jurcewicz, Wspólna Polityka Rolna Unii Europejskiej, w: P. Czechowski (red.), Prawo rolne, Warszawa 2019, 
dukcję tę zaangażowana jest duża liczba drobnych rolników, a oferowana im pomoc przyczynia się do utrzymania tkanki społecznej na obszarach wiejskich. O tematyce tej decydują także względy poznawcze, praktyczne, w tym dotyczące stanowienia i stosowania prawa. Zagadnienia wdrażania instrumentarium prawnego w celu ograniczania ryzyka lub skutków jego występowania w działalności rolniczej są przedmiotem prac legislacyjnych. Projektowanie i wdrażanie określonych narzędzi pomocowych pozwala na minimalizowanie występowania negatywnych zdarzeń. Brak właściwej ochrony trwałości warsztatu pracy producenta rolnego może zaś przyczyniać się nawet do zaprzestania działalności rolniczej.

Rozważania te stanowią próbę odpowiedzi na pytanie, czy i w jakim stopniu wymienione formy wsparcia chronią producenta rolnego i wzmacniają trwałość jego warsztatu pracy. Koncentrują się one na analizie rozwiązań normatywnych zawartych w PROW 2014-2020 dotyczących oferowanych instrumentów wsparcia inwestycji zapobiegających zniszczeniu oraz przywracających potencjał produkcji rolnej. W ramach tych działań mają być wdrażane środki zapobiegawcze i naprawcze, które służą ograniczeniu skutków prawdopodobnych klęsk żywiołowych, niekorzystnych zjawisk klimatycznych i katastrof. Pomoc zwiększająca trwałość warsztatu pracy producenta rolnego przybiera formę ex ante oraz ex post. W pierwszym przypadku chodzi o wsparcie inwestycji w środki zapobiegawcze w celu ograniczenia skutków prawdopodobnych zdarzeń losowych lub innych wymienionych niekorzystnych zjawisk. Przykładem działań prewencyjnych, które umożliwiają dokonanie określonych inwestycji zapobiegających zniszczeniu potencjału produkcji rolnej, są „Inwestycje mające na celu ochronę wód przed zanieczyszczeniem azotanami pochodzącymi ze źródeł rolniczych" oraz „Wsparcie inwestycji w środki zapobiegawcze, których celem jest ograniczenie skutków prawdopodobnych klęsk żywiołowych, niekorzystnych zjawisk klimatycznych i katastrof". Natomiast uruchomienie pomocy ex post następuje po zajściu określonego zdarzenia, którego skutkiem jest powstanie szkody, jak ma to miejsce w działaniu „Przywracanie potencjału produkcji rolnej zniszczonego w wyniku wystąpienia klęsk żywiołowych”.

Oprócz analizy zasad przyznawania pomocy w ramach wymienionych instrumentów wsparcia PROW 2014-2020 w artykule dokonana zostanie ocena poziomu wykorzystania przez producentów rolnych zaoferowanej pomocy publicznej na podstawie danych statystycznych, uzyskanych w ramach

s. 83-85; M. Spychalski, Wpływ Wspólnej Polityki Rolnej Unii Europejskiej na rozwój sektora rolnego i obszarów wiejskich $w$ Polsce - przewidywane korzyści i koszty w pierwszych latach czlonkostwa, „International Journal of Management and Economics” 2004, t. 16, s. 88; A. Jurcewicz, B. Kozłowska, E. Tomkiewicz, Wspólna polityka rolna. Zagadnienia prawne, Warszawa 2007, s. 40. 
dostępu do informacji publicznej z Agencji Restrukturyzacji i Modernizacji Rolnictwa (ARiMR). Zadaniem Agencji jest przede wszystkim wspieranie przedsięwzięć związanych ze wznowieniem produkcji w gospodarstwach rolnych i działach specjalnych produkcji rolnej, w których wystąpiły szkody spowodowane przez klęski żywiołowe w rozumieniu przepisów o ubezpieczeniach upraw rolnych i zwierząt gospodarczych ${ }^{8}$.

2. Ochrona wód przed zanieczyszczeniami ze źródeł rolniczych jest ważnym obszarem wspólnotowej polityki ochrony wód oraz najpoważniejszym problemem na styku ochrony środowiska i utrzymania trwałości warsztatu pracy producenta rolnego. Mając to na uwadze, Rada Wspólnoty Europejskiej przyjęła w $1991 \mathrm{r}$. dyrektywę dotyczącą ochrony wód przed zanieczyszczeniami powodowanymi przez azotany pochodzenia rolniczego $^{9}$. Zgodnie z nią państwa członkowskie mają do wyboru dwa sposoby wdrażania jej postanowień. Pierwszy polega na sporządzeniu wykazu wód zanieczyszczonych lub zagrożonych zanieczyszczeniem oraz ustanowieniu wykazu obszarów szczególnie narażonych na zanieczyszczenie związkami azotu ze źródeł rolniczych (OSN). Drugi polega na ustanowieniu i wdrożeniu „Programu działań” na terenie całego kraju. Państwo członkowskie jest zwolnione wtedy z obowiązku wyznaczania wód wrażliwych i OSN ${ }^{10}$.

W ramach priorytetów nakreślonych na poziomie Unii Europejskiej państwa członkowskie mają możliwość wyboru konkretnego instrumentarium, którego stosowanie ma służyć rozwiązaniu problemów rolnictwa danego państwa członkowskiego, i położenia nacisku na elementy specyficzne wymagające szczególnego wsparcia. Stąd przed wprowadzeniem możliwości ubiegania się o wsparcie w ramach działania PROW 2014-2020 „Inwestycje mające na celu ochronę wód przed zanieczyszczeniem azotanami pochodzącymi ze źródeł rolniczych" pomoc w podobnym zakresie była przyznawana $\mathrm{w}$ ramach „Inwestycji $\mathrm{w}$ gospodarstwach położonych na obszarach OSN"11. W tym przypadku chodzi o wsparcie ex ante inwestycji w środki

${ }^{8}$ Zob. art. 4 pkt 2 ustawy z 9 maja 2008 r. o Agencji Restrukturyzacji i Modernizacji Rolnictwa, Dz. U. 2016, poz. 1512 ze zm. Na temat ARiMR: M Jarosiewicz, K. Kozikowska, M. Wujczyk, Prawo rolne, Warszawa 2011, s. 188-191.

9 Dyrektywa nr 91/676/EWG Rady z 12 grudnia 1991 r., Dz. Urz. WE L 375 (dalej: dyrektywa azotanowa).

${ }_{10}$ Zob. art. 3 dyrektywy azotanowej.

${ }^{11}$ Rozporządzenie Ministra Rolnictwa i Rozwoju Wsi z 23 października 2015 r. w sprawie szczegółowych warunków i trybu przyznawania oraz wypłaty pomocy finansowej na operacje typu „Inwestycje w gospodarstwach położonych na obszarach OSN” w ramach poddziałania „Wsparcie inwestycji w gospodarstwach rolnych" objętego Programem Rozwoju Obszarów Wiejskich na lata 2014-2020, Dz. U. poz. 1795. 
zapobiegawcze. Pomoc ta była skierowana do gospodarstw położonych na obszarach, które w 2012 r. po raz pierwszy zostały wyznaczone jako szczególnie narażone na zanieczyszczenia azotem ze źródeł rolniczych (OSN) i dla których zostały wprowadzone, w drodze aktów prawa miejscowego, programy działań mające na celu ograniczenie odpływu azotu ze źródeł rolniczych na lata 2012-2016 ${ }^{12}$.

Ze względu na wygaśnięcie programów działań na lata 2012-2016, w celu zapobiegania dalszemu zanieczyszczeniu, jak również zmniejszaniu zanieczyszczenia wód azotanami pochodzącymi ze źródeł rolniczych ${ }^{13}$, opracowany i wdrożony został obowiązujący na terenie całego kraju program pod nazwą „Program działań mających na celu zmniejszenie zanieczyszczenia wód azotanami pochodzącymi ze źródeł rolniczych oraz zapobieganie dalszemu zanieczyszczeniu"14. Wprowadzenie tego programu zostało uchwalone w ustawie Prawo wodne z 20 lipca 2017 r. ${ }^{15}$, na mocy której wszystkie podmioty wymienione w art. 102 ust. 1 zostały zobowiązane do odpowiedniego stosowania nawozów zawierających azot ${ }^{16}$. Program ten określa m.in. warunki przechowywania nawozów naturalnych i kiszonek, jak również terminy, w których określone rodzaje podmiotów zobowiązane są dostosować powierzchnię lub pojemność posiadanych miejsc do przechowywania nawozów naturalnych.

W celu ułatwienia producentom rolnym dostosowania się do wymogów w zakresie przechowywania nawozów naturalnych określonych w Programie działań ARiMR wdrożyła nowy typ wparcia w ramach PROW 2014-2020 pod nazwą „Inwestycje mające na celu ochronę wód przed zanieczyszczeniem azotanami pochodzącymi ze źródeł rolniczych", w którym zmienione zostały

12 Wyrok WSA we Wrocławiu z 23 maja 2018 r., sygn. akt: III SA/Wr 121/18, LEX nr 2557734; wyrok WSA w Szczecinie z 2 lutego 2017 r., sygn. akt: I SA/Sz 1228/16, LEX nr 2237668 .

${ }^{13} \mathrm{Na}$ temat problemu zanieczyszczenia wód azotem pochodzenia rolniczego: K. Jóźwiakowski, W. Siuda, Ochrona i ksztaltowanie zasobów wodnych na terenach wiejskich, Warszawa 2017; J. Igras, M. Pastuszak, Udziat polskiego rolnictwa w emisji zwiazków fosforu i azotu do Battyku, Puławy 2009; A. Józefaciuk, E. Nowocień, R. Wawer, Erozja gleb w Polsce-skutki środowiskowe i gospodarcze, działania zaradcze, Puławy 2014; J. Igras, Dobre praktyki rolnicze w nawożeniu użytków rolnych, Radom 2013.

${ }^{14}$ Załącznik do rozporządzenia Rady Ministrów z 12 lutego 2020 r. w sprawie przyjęcia „Programu działań mających na celu zmniejszenie zanieczyszczenia wód azotanami pochodzącymi ze źródeł rolniczych oraz zapobieganie dalszemu zanieczyszczeniu”, Dz. U. poz. 243.

${ }^{15}$ Dz. U. poz. 1566.

${ }^{16}$ Produkcję rolną, w tym działy specjalne produkcji rolnej, oraz działalność, w ramach której przechowywane są odchody zwierzęce lub stosowane nawozy, prowadzi się w sposób zapobiegający zanieczyszczeniu wód azotanami pochodzącymi ze źródeł rolniczych i ograniczający takie zanieczyszczenie. 
w stosunku do poprzedniego rodzaju wsparcia kryteria dostępu, jak również zakres kosztów podlegających dofinansowaniu. Jednocześnie w związku $\mathrm{z}$ rozszerzeniem zasięgu wdrażania tego instrumentu pomocowego na cały kraj rozszerzył się krąg potencjalnych beneficjentów tego wsparcia.

O pomoc w ramach działania „Inwestycje mające na celu ochronę wód przed zanieczyszczeniem azotanami pochodzącymi ze źródeł rolniczych" może ubiegać się rolnik (tj. osoba fizyczna, osoba prawna, jednostka organizacyjna nieposiadająca osobowości prawnej, oddział przedsiębiorcy zagranicznego, wspólnik spółki cywilnej), jeżeli ${ }^{17}$ :

a) jest posiadaczem gospodarstwa rolnego, w rozumieniu art. 4 ust. 1 lit. b rozporządzenia Parlamentu Europejskiego i Rady (UE) nr 1307/2013 z 17 grudnia 2013 r. ustanawiającego przepisy dotyczące płatności bezpośrednich dla rolników na podstawie systemów wsparcia w ramach Wspólnej Polityki Rolnej oraz uchylającego rozporządzenie Rady (WE) nr 637/2008 i rozporządzenie Rady (WE) nr 73/2009 ${ }^{18}$, położonego na terytorium kraju ${ }^{19}$;

b) w gospodarstwie, którego jest posiadaczem, prowadzi chów lub hodowlę zwierząt gospodarskich w rozumieniu przepisów ustawy z 29 czerwca 2007 r. o organizacji hodowli i rozrodzie zwierząt gospodarskich ${ }^{20}$, z wyłączeniem chowu lub hodowli drobiu powyżej 40 tys. stanowisk lub chowu lub hodowli świń powyżej 2 tys. stanowisk dla świń o wadze ponad $30 \mathrm{~kg}$ lub 750 stanowisk dla macior;

c) został mu nadany numer identyfikacyjny w trybie przepisów ustawy z 18 grudnia 2003 r. o krajowym systemie ewidencji producentów, ewidencji gospodarstw rolnych oraz ewidencji wniosków o przyznanie płatności ${ }^{21}$;

d) nie podlega wykluczeniu z ubiegania się o przyznanie pomocy na podstawie przepisów $\mathrm{UE}^{22}$.

17 Rozporządzenie Ministra Rolnictwa i Rozwoju Wsi z 5 grudnia 2018 r. zmieniające rozporządzenie w sprawie szczegółowych warunków i trybu przyznawania oraz wypłaty pomocy finansowej na operacje typu "Inwestycje w gospodarstwach położonych na obszarach OSN" w ramach poddziałania „Wsparcie inwestycji w gospodarstwach rolnych” objętego Programem Rozwoju Obszarów Wiejskich na lata 2014-2020, Dz. U. poz. 2317.

18 Dz. Urz. UE L 347 z 20.12.2013, s. 608 ze zm.

${ }^{19}$ Gospodarstwo rolne oznacza wszystkie jednostki wykorzystywane do działalności rolniczej i zarządzane przez rolnika, znajdujące się na terytorium tego samego państwa członkowskiego.

${ }^{20}$ Dz. U. 2017, poz. 2132.

${ }^{21}$ Dz. U. 2017, poz. 1853.

22 Rozporządzenie delegowane Komisji (UE) nr 640/2014 z dnia 11 marca 2014 r. uzupełniające rozporządzenie Parlamentu Europejskiego i Rady (UE) nr 1306/2013 w odniesieniu do zintegrowanego systemu zarządzania i kontroli oraz warunków odmowy lub wycofania płatności oraz do kar administracyjnych mających zastosowanie do płatności bezpośrednich, wsparcia rozwoju obszarów wiejskich oraz zasady wzajemnej zgodności (Dz. Urz. UE L 181 z 20.06.2014, 
Pomoc w ramach działania „Inwestycje mające na celu ochronę wód przed zanieczyszczeniem azotanami pochodzącymi ze źródeł rolniczych" może być przyznana na operację polegającą na realizacji inwestycji, która zapewni dostosowanie gospodarstwa do wymagań określonych w Programie działań, dotyczących warunków przechowywania nawozów naturalnych wyprodukowanych w gospodarstwie lub doposażenie gospodarstwa w urządzenia do aplikowania nawozów naturalnych. Pomoc przyznaje się w formie refundacji części kosztów kwalifikowalnych ${ }^{23}$, do których zalicza się koszty budowy, przebudowy lub zakupu zbiorników do przechowywania nawozów naturalnych płynnych, płyt do gromadzenia i przechowywania nawozów naturalnych stałych, zbiorników lub płyt do przechowywania kiszonek oraz zakupu aplikatorów nawozów naturalnych w postaci płynnej. Wsparcie przyznaje się i wypłaca do wysokości limitu, który w okresie realizacji PROW 2014-2020 wynosi maksymalnie 100 tys. zł na jednego beneficjenta i na jedno gospodarstwo. Inwestycje objęte dofinansowaniem, oprócz dbałości o ochronę środowiska naturalnego, przyczyniają się również do zachowania trwałości warsztatu pracy producenta rolnego, szczególnie prowadzącego produkcję zwierzęcą.

Na podstawie danych uzyskanych z Departamentu Analiz i Sprawozdawczości Agencji Restrukturyzacji i Modernizacji Rolnictwa ${ }^{24}$ można stwierdzić niewielkie zainteresowanie uzyskaniem pomocy w ramach naboru wniosków w 2016 r. dla operacji „Inwestycje w gospodarstwach położonych na obszarach OSN". W całym kraju złożono jedynie 280 wniosków o pomoc finansową na łączną kwotę ponad $11 \mathrm{mln} \mathrm{z}^{25}$. Po opracowaniu i wdrożeniu obowiązującego na terenie całego kraju programu pod nazwą „Program działań mających na celu zmniejszenie zanieczyszczenia wód azotanami pochodzącymi ze źródeł rolniczych oraz zapobieganie dalszemu zanieczyszczeniu" liczba wniosków znacznie wzrosła. We wszystkich naborach wnio-

\footnotetext{
s. 48 ze zm.) oraz przepisów Unii Europejskiej wydanych w trybie tego rozporządzenia lub przepisów odrębnych.

${ }^{23} 60 \%$ kosztów kwalifikowalnych - w przypadku operacji realizowanej przez „młodego rolnika" oraz 50\% kosztów kwalifikowalnych - w przypadku operacji realizowanej przez rolnika niebędącego „młodym rolnikiem”.

${ }^{24}$ Dane dotyczące poziomu wykorzystania pomocy w ramach operacji 4.1.2 „Inwestycje mające na celu ochronę wód przed zanieczyszczeniem azotanami pochodzącymi ze źródeł rolniczych" pochodzą z marca $2020 \mathrm{r}$.

${ }^{25} \mathrm{Na}$ niewielkie wykorzystanie pomocy finansowej w ramach „Inwestycji w gospodarstwach położonych na obszarach OSN" zwracała uwagę w swoim raporcie Najwyższa Izba Kontroli, wskazując na zaledwie 7-proc. wykorzystanie limitu finansowego wynoszącego ponad $162 \mathrm{mln}$ zł w skali całego kraju. Zob. NIK, Informacja o wynikach kontroli NIK. Zapobieganie zanieczyszczeniu wód związkami azotu ze źródet rolniczych, Warszawa 2018, s. 17.
} 
sków przeprowadzonych w 2019 oraz 2020 r. łącznie w całej Polsce o pomoc aplikowało ponad 5 tys. osób na kwotę prawie $380 \mathrm{mln} \mathrm{z}^{26}$, co świadczy o tym, że dokonane zmiany legislacyjne zintensyfikowały działania ukierunkowane na lepszą ochronę zasobów wodnych, a co za tym idzie - w znaczący sposób chronią producenta rolnego i zapewniają trwałość jego warsztatu pracy.

3. Przykładem wsparcia finansowego przybierającego formę ex ante (udzielanego przed wystąpieniem ryzyka klęsk żywiołowych) jest kolejny instrument PROW 2014-2020, którego rozstrzygnięcia merytoryczne zawiera rozporządzenie Ministra Rolnictwa i Rozwoju Wsi z 14 lipca 2017 r. w sprawie szczegółowych warunków i trybu przyznawania oraz wypłaty pomocy finansowej na operacje „Inwestycje zapobiegające zniszczeniu potencjału produkcji rolnej” w ramach poddziałania „Wsparcie inwestycji w środki zapobiegawcze, których celem jest ograniczenie skutków prawdopodobnych klęsk żywiołowych, niekorzystnych zjawisk klimatycznych i katastrof"27.

W ramach tego działania pomoc przyznaje się spółce wodnej, o której mowa w przepisach ustawy z 20 lipca 2017 r. - Prawo wodne ${ }^{28}$, lub związkowi spółek wodnych na realizację operacji dotyczącej zaopatrzenia w sprzęt do utrzymywania urządzeń wodnych służących zabezpieczeniu gospodarstw rolnych przed zalaniem, podtopieniem bądź nadmiernym uwilgoceniem spowodowanym przez powódź lub deszcz nawalny ${ }^{29}$. Pomoc jest udzielana w formie refundacji części poniesionych i udokumentowanych kosztów kwalifikowalnych operacji w wysokości do $80 \%$ tych kosztów. Wsparcie finansowe przyznaje się i wypłaca do wysokości limitu, który w okresie realizacji programu wynosi maksymalnie $1 \mathrm{mln}$ zł na jednego beneficjenta w przypadku spółki wodnej lub związku spółek wodnych, jeżeli ponad połowę członków spółki stanowią rolnicy posiadający grunty rolne. Kolejnym warunkiem otrzymania wsparcia jest to, aby spółka została utworzona do wykonywania, utrzymania oraz eksploatacji urządzeń służących do ochrony gospodarstw członków spółki wodnej przed powodzią lub melioracji wodnych oraz prowadzenia racjonalnej gospodarki na terenach zmeliorowanych będących w posiadaniu członków spółki wodnej. Kolejność przyznawania pomocy ustala się na podstawie danych zawartych w uchwale $\mathrm{w}$ sprawie

26 Poziom wykorzystania przez producentów rolnych zaoferowanej pomocy publicznej wynosi $33,01 \%$.

27 Dz. U. poz. 1478 ze zm.

${ }_{28}^{28}$ Dz. U. 2018, poz. 2268.

${ }^{29}$ I. Lipińska, Prawne aspekty zarządzania ryzykiem $w$ działalności rolniczej, Warszawa 2019, s. 381. 
budżetu lub planu finansowego spółki wodnej bądź związku spółek wodnych na rok, w którym został złożony wniosek, lub w zaświadczeniu wystawionym przez wójta, burmistrza lub prezydenta, że spółka wodna albo związek spółek wodnych działa na terenie gminy poszkodowanej przez powodzie lub deszcze nawalne co najmniej dwukrotnie od 1 stycznia $1997 \mathrm{r}$.

Wsparcie otrzymuje osoba na podstawie umowy o przyznaniu pomocy zawieranej z dyrektorem oddziału regionalnego ARiMR. Stosunek cywilnoprawny pozwala na należytą kontrolę wykorzystania środków pomocy. Należy zgodzić się ze Stanisławem Prutisem, według którego umowa jest instrumentem elastycznym, pozwalającym - w ramach zasady swobody umów - na indywidualne określenie sposobu wykorzystania środków, co jest szczególnie ważne, gdy pomoc udzielana jest na cele inwestycyjne ${ }^{30}$. Procedura cywilna zabezpiecza kontrolę spełniania przesłanek do ubiegania się o uzyskanie pomocy oraz daje prawo do uzyskania pomocy w przypadku spełnienia określonych przesłanek.

Ponadto w ramach omawianego instrumentu wsparcia PROW 20142020 pomoc przyznaje się rolnikowi, który jest posiadaczem samoistnym lub zależnym nieruchomości położonej na terytorium kraju, na której prowadzi chów lub hodowlę nie mniej niż 50 świń i planuje realizację operacji mającej na celu zapobieganie rozprzestrzenianiu się afrykańskiego pomoru świń (ASF) ${ }^{31}$ poprzez: ogrodzenie chlewni wraz z terenem koniecznym do realizacji obsługi świń, utworzenie lub zmodernizowanie zadaszonej niecki do dezynfekcji, zakup urządzeń do dezynfekcji, przebudowę/remont pomieszczeń w celu utrzymywania świń w gospodarstwie rolnym w odrębnych, zamkniętych pomieszczeniach ${ }^{32}$.

${ }^{30}$ S. Prutis, Dobór instrumentów prawnych stużących wsparciu rozwoju obszarów wiejskich, „Studia Iuridica Agraria” 2009, t. VII, s. 198.

${ }^{31}$ Decyzją wykonawczą nr C(2016)8568 Rady z 9 grudnia 2016 r. zatwierdzającą zmianę programu rozwoju obszarów wiejskich dla Polski do celów wsparcia w ramach Europejskiego Funduszu Rolnego na rzecz Rozwoju Obszarów Wiejskich oraz zmieniającą decyzję wykonawczą nr C(2014)9783 Komisji Komisja Europejska zatwierdziła zmiany Programu Rozwoju Obszarów Wiejskich na lata 2014-2020. Zmiany dotyczyły wprowadzenia do Programu Rozwoju Obszarów Wiejskich na lata 2014-2020 rozwiązań na rzecz działań wspierających ograniczenie skutków wystąpienia przypadków afrykańskiego pomoru świń (ASF) na terenie Polski w typie operacji „Premie na rozpoczęcie działalności pozarolniczej” i „Restrukturyzacja małych gospodarstw” oraz w poddziałaniu „Wsparcie inwestycji w środki zapobiegawcze, których celem jest ograniczenie skutków prawdopodobnych klęsk żywiołowych, niekorzystnych zjawisk klimatycznych i katastrof". Zob. I. Lipińska, Prawna ochrona unijnego rynku rolnego w oparciu o nadzwyczajne środki wsparcia, „Przegląd Prawa Rolnego” 2017, nr 1, s. 90-94.

${ }^{32}$ I. Lipińska, Prawne determinanty bioasekuracji zwierząt gospodarskich w Unii Europejskiej i Polsce, w: P. Litwiniuk (red.), Integracja europejska jako determinanta polityki wiejskiej. Aspekty prawne, Warszawa 2017, s. 427-442. 
Pomoc jest udzielana w formie refundacji części poniesionych i udokumentowanych kosztów kwalifikowalnych operacji w wysokości do 80\% kosztów kwalifikowalnych. Wsparcie przyznaje się na podstawie umowy o przyznaniu pomocy zawieranej przez dyrektora oddziału regionalnego ARiMR. Pomoc wypłaca się do wysokości limitu, który w okresie realizacji programu wynosi maksymalnie 100 tys. zł na jednego beneficjenta w przypadku rolnika, który jest posiadaczem samoistnym lub zależnym nieruchomości położonej na terytorium Polski i prowadzi chów lub hodowlę nie mniej niż 50 świń średniorocznie na nieruchomości położonej na terytorium kraju.

Za przyjęciem tego kierunku wsparcia w obu przypadkach przemawiają przede wszystkim względy bezpieczeństwa i ochrony zdrowia zwierząt gospodarskich. Pojawienie się w stadzie ASF prowadzi do dużych spadków produkcji i najczęściej skutkuje 100-proc. śmiertelnością zwierząt, co wiąże się z dużymi stratami finansowymi z powodu kosztów zwalczania tej choroby w gospodarstwach, w których zostanie stwierdzona. Uzasadnia to rozpoczęcie działań prewencyjnych wynikających z programu bioasekuracji, mających na celu ograniczanie rozprzestrzeniania się choroby ${ }^{33}$. Za drugim kierunkiem wsparcia przemawiają z kolei względy klimatyczne. Nadmiar lub niedobór wody decyduje o wzroście plonów na znacznej części użytków rolnych w kraju. Wspomniane zjawiska pogodowe mogą mieć charakter systemowy i dotykać wielu producentów rolnych na rozległych obszarach. W związku z tym ustawodawca przewiduje wsparcie na poprawę i utrzymanie systemów wodno-melioracyjnych. Analiza danych uzyskanych z Departamentu Analiz i Sprawozdawczości Agencji Restrukturyzacji i Modernizacji Rolnictwa ${ }^{34}$ wskazuje na duże zainteresowanie tym działaniem. We wszystkich naborach wniosków przeprowadzonych w latach 2017-2019 w całej Polsce o pomoc starało się prawie 5 tys. osób na kwotę ponad $340 \mathrm{mln} \mathrm{zt}^{35}$. Wpływ na to miała niewątpliwie 80-proc. refundacja ponoszonych kosztów kwalifikowanych, podczas gdy w innych

${ }^{33}$ Główny lekarz weterynarii przygotował „Program bioasekuracji mający na celu zapobieganie szerzeniu się afrykańskiego pomoru świń”. Zob. rozporządzenie Ministra Rolnictwa i Rozwoju Wsi z 29 lipca 2016 r. zmieniające rozporządzenie w sprawie wprowadzenia „Programu bioasekuracji mającego na celu zapobieganie szerzeniu się afrykańskiego pomoru świń” na lata 2015-2018, Dz. U. poz. 1153 ze zm.

${ }^{34}$ Dane dotyczące poziomu wykorzystania pomocy w ramach wsparcia inwestycji w środki zapobiegawcze, których celem jest ograniczenie skutków prawdopodobnych klęsk żywiołowych, niekorzystnych zjawisk klimatycznych i katastrof, pochodzą z marca $2020 \mathrm{r}$.

35 Poziom wykorzystania przez producentów rolnych zaoferowanej pomocy publicznej wynosi $31,07 \%$. 
działaniach PROW 2014-2020 wymiar pomocy wynosi zazwyczaj 50\%. Analizowane formy wsparcia znacząco wpływają na zwiększenie ochrony warsztatu pracy rolnika.

4. Do działań o szczególnym znaczeniu dla priorytetu trzeciego PROW 2014-2020 „Poprawa organizacji łańcucha żywnościowego i promowania zarządzania ryzykiem w rolnictwie” zalicza się działanie „Przywracanie potencjału produkcji rolnej zniszczonego w wyniku wystąpienia klęsk żywiołowych" ${ }^{36}$. W ramach tego instrumentu wsparcia ${ }^{37}$ pomoc przyznawana jest rolnikowi, jeżeli jest posiadaczem samoistnym lub zależnym gospodarstwa rolnego bądź nieruchomości służącej do prowadzenia produkcji w zakresie działów specjalnych produkcji rolnej ${ }^{38}$, w których w roku składania wniosku o przyznanie pomocy lub w roku poprzedzającym rok składania wniosku o przyznanie pomocy wystąpiły szkody spowodowane przez co najmniej jedno ze zdarzeń losowych, klęsk żywiołowych wymienionych w art. 3 ust. 2 pkt 2-6 i 8-11a ustawy z 7 lipca 2005 r. o ubezpieczeniach upraw rolnych i zwierząt gospodarskich ${ }^{39}$. Jest to zatem pomoc ex post udzielana po zajściu określonego zdarzenia.

Szkody oszacowane przez komisję powołaną przez wojewodę właściwego ze względu na miejsce ich wystąpienia powinny ${ }^{40}$ :

a) wynosić co najmniej 30\% średniej rocznej produkcji rolnej w gospodarstwie z 3 lat poprzedzających okres, w którym wystąpiła szkoda, albo z 3 lat w okresie 5-letnim poprzedzającym rok, w którym wystąpiła szkoda ${ }^{41}$,

${ }^{36}$ P. Wojciechowski, Program Rozwoju Obszarów Wiejskich jako podstawowy instrument polityki rozwoju obszarów wiejskich w Polsce, w: P. Czechowski (red.), Prawo rolne, s. 571.

${ }^{37}$ Warunki i tryb przyznawania pomocy, w tym szczegółowe informacje o prawach i obowiązkach beneficjentów, określa rozporządzenie Ministra Rolnictwa i Rozwoju Wsi z 4 listopada 2016 r. w sprawie szczegółowych warunków i trybu przyznawania oraz wypłaty pomocy finansowej na operacje typu „Inwestycje odtwarzające potencjał produkcji rolnej” w ramach poddziałania „Wsparcie inwestycji w odtwarzanie gruntów rolnych i przywracanie potencjału produkcji rolnej zniszczonego w wyniku klęsk żywiołowych, niekorzystnych zjawisk klimatycznych i katastrof" objętego Programem Rozwoju Obszarów Wiejskich na lata 2014-2020, Dz. U. poz. 1858.

${ }_{38}$ Wyrok NSA z 17 września 2015 r., sygn. akt: II GSK 1780/14, LEX nr 1986688; wyrok NSA z 5 września 2014 r., sygn. akt: II GSK 1101/13, LEX nr 1572590.

39 Tekst jedn. Dz. U. 2019, poz. 477. Są nimi szkody spowodowane przez: huragan, powódź, deszcz nawalny, piorun, obsunięcie się ziemi, lawinę, suszę, ujemne skutki przezimowania, przymrozki wiosenne.

${ }^{40}$ Wyrok NSA z 30 maja 2014 r., sygn. akt: II GSK 396/13, LEX nr 1579373.

${ }^{41}$ Wyrok WSA w Opolu z 7 kwietnia 2016 r., sygn. akt: II SA/Op 98/16, LEX nr 2015473. 
z pominięciem roku o najwyższej i najniższej produkcji w gospodarstwie w uprawach rolnych, zwierzętach gospodarskich lub rybach;

b) dotyczyć trwałego składnika gospodarstwa, którego odtworzenie wymaga poniesienia kosztów wchodzących w zakres kosztów kwalifikowalnych. Dofinansowanie można otrzymać na zakup nowych maszyn lub urządzeń rolniczych w miejsce tych, które zostały zniszczone w wyniku klęsk żywiołowych ${ }^{42}$. Pomoc może być również przyznana na odtworzenie plantacji wieloletnich czy sadów lub stada podstawowego ${ }^{43}$.

Pomoc w ramach działania „Wsparcie inwestycji w odtwarzanie gruntów rolnych i przywracanie potencjału produkcji rolnej zniszczonego w wyniku klęsk żywiołowych, niekorzystnych zjawisk klimatycznych i katastrof' przyznaje się i wypłaca do wysokości wartości szkód w składnikach gospodarstwa oszacowanych przez wspomnianą komisję, których odtworzenia dotyczy wniosek o przyznanie pomocy, pomniejszonej o kwotę odszkodowania uzyskanego z tytułu ubezpieczenia tych składników gospodarstwa uszkodzonych lub zniszczonych w wyniku wystąpienia klęski żywiołowej. Prawodawca uznał, podobnie jak w poprzednim okresie projektowania Wspólnej Polityki Rolnej, że państwa członkowskie powinny zapewnić, by nie wystąpiła nadwyżka rekompensaty w wyniku połączenia unijnych, krajowych i prywatnych systemów rekompensat.

Omawiane wsparcie ma umożliwić przywrócenie poszkodowanym rolnikom utraconej zdolności produkcyjnej przez odtworzenie składnika gospodarstwa rolnego, który uległ zniszczeniu lub uszkodzeniu. W odróżnieniu od pozostałych omawianych mechanizmów wsparcia uruchomienie go następuje po zajściu określonego zdarzenia, którego skutkiem jest powstanie szkody. Pomoc przybiera formę refundacji do $80 \%$ kosztów kwalifikowanych. Wysokość limitu przyznanego w ramach tego działania w okresie realizacji programu wynosi maksymalnie 300 tys. zł na jednego beneficjenta i na jedno gospodarstwo. Jeżeli rolnik nie zawarł umowy ubezpieczenia obowiązkowego upraw w rozumieniu przepisów o ubezpieczeniach upraw rolnych i zwierząt gospodarskich, ważnej na dzień wystąpienia szkody w składniku gospodarstwa, którego odtworzenie wymaga poniesienia kosztów dotyczących odtwarzania plantacji chmielu, sadów, plantacji krzewów owocowych gatunków owocujących efektywnie dłużej niż 5 lat, to kwotę pomocy na odtworzenie tego składnika gospodarstwa pomniejsza się o $50 \%$.

${ }^{42}$ A. Suchoń, Wybrane zagadnienia prawne pomocy de minimis $w$ rolnictwie, „Przegląd Prawa Rolnego" 2011, nr 1, s. 190.

${ }^{43}$ Plantacją wieloletnią jest plantacja, której okres użytkowania wynosi kilka lat, tj. ponad dwa lata. Zob. wyrok WSA w Warszawie z 24 września 2015 r., sygn. akt: V SA/Wa 1540/15, LEX Nr 1972654. 
Wsparcie to nie jest udzielane jedynie z powodu straty dochodu wynikającej z klęski żywiołowej, dlatego zainteresowanie uzyskaniem pomocy w ramach naborów wniosków dla operacji „Inwestycje odtwarzające potencjał produkcji rolnej" PROW 2014-2020 było niewielkie, szczególnie podczas naboru wniosków w 2019 r. Wykorzystanie tego instrumentu w skali kraju wyniosło jedynie $18,12 \%$. We wszystkich naborach wniosków przeprowadzonych w 2017 i 2019 r. w całej Polsce o pomoc starało się łącznie prawie 1,3 tys. osób na kwotę ponad $19 \mathrm{mln} \mathrm{zf}^{44}$. Dane wskazują, że to narzędzie wsparcia nie wpływa znacząco na ochronę warsztatu producentów rolnych i wymaga zmian legislacyjnych zwiększających absorpcję środków przez potencjalnych beneficjentów ${ }^{45}$. W tym przypadku zasadne wydaje się też, aby pomoc była przyznawana $\mathrm{z}$ wykorzystaniem instrumentu, jakim jest decyzja administracyjna, a nie umowa, która obecnie stanowi podstawę przyznania wsparcia. Udzielenie pomocy wymaga sprawdzenia przesłanek jej przyznawania oraz szybkiego rozstrzygnięcia, co przemawia za wykorzystaniem instrumentu decyzji, szczególnie gdy wnioskodawca potrzebuje niezwłocznej pomocy finansowej w celu odbudowy zdolności produkcyjnej swojego warsztatu pracy ${ }^{46}$.

5. Ochrona trwałości warsztatu pracy producenta rolnego często wiąże się z koniecznością zaangażowania pewnych środków finansowych. Odnosi się to do czynności mających na celu zarówno ograniczanie ryzyka, jak i niwelowanie negatywnych skutków zdarzeń objętych ryzykiem. W preambule do podstawowego rozporządzenia Parlamentu Europejskiego i Rady (UE) nr 1305/2013 z 17 grudnia 2013 r. w sprawie wsparcia rozwoju obszarów wiejskich przez Europejski Fundusz Rolny na rzecz Rozwoju Obszarów Wiejskich (EFRROW) i uchylającego rozporządzenie Rady (WE) nr 1698/2005 $5^{47}$ prawodawca wskazał, że potencjał produkcyjny sektora rolnictwa jest bardziej niż inne sektory narażony na szkody w wyniku klęsk żywiołowych, niekorzystnych zjawisk klimatycznych i katastrof. Dlatego aby wspomóc rentowność i konkurencyjność gospodarstw w obliczu takich klęsk lub zjawisk, należy udzielać wsparcia stanowiącego dla rolników po-

${ }^{44}$ Dane dotyczące poziomu wykorzystania pomocy w ramach operacji „Inwestycje odtwarzające potencjał produkcji rolnej" uzyskane w ramach dostępu do informacji publicznej, otrzymane z Departamentu Analiz i Sprawozdawczości Agencji Restrukturyzacji i Modernizacji Rolnictwa (stan na marzec 2020 r.).

${ }^{45} \mathrm{Na}$ temat doboru instrumentów prawnych dla lepszej obsługi wsparcia rozwoju obszarów wiejskich: S. Prutis, Dobór instrumentów prawnych ..., s. 200.

${ }^{46}$ Ibidem, s. 197-199.

${ }^{47}$ Dz. Urz. UE L 347, s. 487. 
moc w przywracaniu potencjału produkcji rolnej, który uległ zniszczeniu. Temu właśnie służy pomoc finansowa ze środków Europejskiego Funduszu Rolnego na rzecz Rozwoju Obszarów Wiejskich, która realizowana jest w Polsce jako jednolity program pomocowy ${ }^{48}$. PROW 2014-2020 posiada zaś instrumenty wsparcia inwestycji zapobiegających zniszczeniu oraz przywracających potencjał produkcji rolnej zniszczony działaniem klęski żywiołowej ${ }^{49}$.

W zależności od czasu udzielenia pomocy może ona przybierać formę ex ante, czyli wsparcia udzielanego przed wystąpieniem ryzyka, oraz ex post - po jego zajściu. W produkcji rolniczej najczęściej udzielane jest to drugie. Jest ono ukierunkowane na łagodzenie wpływu negatywnego zdarzenia na sytuację ekonomiczną rolnika po jego wystąpieniu. W przypadku operacji „Inwestycje odtwarzające potencjał produkcji rolnej” omówione wsparcie o ściśle inwestycyjnym charakterze prowadzi do odbudowy zdolności produkcyjnych elementów warsztatu pracy producenta rolnego, zniszczonego przez nieoczekiwane zmiany zachodzące w środowisku przyrodniczym. Ma ono na celu restytucję dóbr materialnych. Przyczyną słabego wykorzystania przysługujących w ramach tego działania środków jest warunek łącznego spełnienia dwóch przesłanek do otrzymania pomocy, czyli szkody określonej na co najmniej 30\% średniej rocznej produkcji rolnej oraz zniszczenia trwałego składnika gospodarstwa. W tej sytuacji można zaproponować rozwiązanie de lege ferenda polegające na zredukowaniu warunków przyznania pomocy jedynie do zobowiązania odtworzenia materialnego składnika gospodarstwa rolnego, który uległ zniszczeniu lub uszkodzeniu.

W ramach działania „Inwestycje mające na celu ochronę wód przed zanieczyszczeniem azotanami pochodzącymi ze źródeł rolniczych" opracowanie i wdrożenie obowiązującego na terenie całego kraju programu pod nazwą „Program działań mających na celu zmniejszenie zanieczyszczenia wód azotanami pochodzącymi ze źródeł rolniczych oraz zapobieganie dalszemu zanieczyszczeniu" przyjętego w ustawie z 20 lipca 2017 r. - Prawo wodne znacznie zwiększyło zainteresowanie potencjalnych beneficjentów pomocą w ramach tego instrumentu oraz pozytywnie wpłynęło na jakość środowiska naturalnego. Wprowadzone wymagania związane z przechowywaniem nawozów naturalnych i kiszonek, jak również terminy, w których określone rodzaje podmiotów zobowiązane są dostosować powierzchnię lub

${ }^{48}$ P. Litwiniuk, Program Rozwoju Obszarów Wiejskich jako dokument programowy i źródło prawa rolnego, Warszawa 2018, s. 79-82.

49 D. Stankiewicz, Polityka rozwoju rolnictwa $i$ wsi, „Studia BAS” 2008, nr 12, s. 62; A. Niewiadomski, Polityka rozwoju obszarów wiejskich, w: P. Czechowski (red.), Prawo rolne, s. 566. 
pojemność posiadanych miejsc do ich składowania, przyniosły zamierzone efekty. Skutkiem tego był znaczny wzrost zainteresowania inwestycjami, które zapewnią dostosowanie gospodarstwa do wymagań określonych w Programie działań, dotyczących warunków przechowywania nawozów wyprodukowanych $\mathrm{w}$ gospodarstwie lub doposażenie go w urządzenia do aplikowania nawozów naturalnych w postaci płynnej.

Jeśli chodzi o działanie „Wsparcie inwestycji w środki zapobiegawcze, których celem jest ograniczenie skutków prawdopodobnych klęsk żywiołowych, niekorzystnych zjawisk klimatycznych i katastrof", to wsparcie to ma wąski zakres przedmiotowy i stanowi odpowiedź na potrzebę interwencji państwa w związku z zagrożeniami epizootycznymi i melioracyjnymi. Ze względu na skalę występujących zjawisk, ich potencjalny efekt i oddziaływanie na bezpieczeństwo środowiska wiejskiego, a także kosztochłonność ustawodawca włączył je w obszar udzielanej pomocy. Wsparcie to jest realizowane tylko $\mathrm{w}$ ramach dwóch operacji: ograniczania możliwości rozszerzania się afrykańskiego pomoru świń (ASF) oraz ochrony produkcji rolnej przed skutkami niekorzystnych zjawisk pogodowych. Mają one charakter prewencyjny i pozwalają na dokonanie inwestycji zapobiegających zniszczeniu potencjału produkcji rolnej na skutek określonych zdarzeń. Biorąc pod uwagę powiększający się w Polsce obszar występowania choroby ASF, co sprawia, że zaostrzane są wymagania ochrony zdrowia zwierząt gospodarskich, oraz zmiany klimatu wpływające na retencje wody, wydaje się zasadne, by ustawodawca ujął omawiane formy wsparcia trwałości warsztatu pracy producenta rolnego w perspektywie finansowej na lata 2021-2027.

Można przyjąć, że obie analizowane formy wsparcia ex ante, czyli „Inwestycje mające na celu ochronę wód przed zanieczyszczeniem azotanami pochodzącymi ze źródeł rolniczych” oraz „Wsparcie inwestycji w środki zapobiegawcze, których celem jest ograniczenie skutków prawdopodobnych klęsk żywiołowych, niekorzystnych zjawisk klimatycznych i katastrof', skutecznie chronią producenta rolnego i zapewniają trwałość jego gospodarowania w odniesieniu do przedstawionych rodzajów ryzyka. Stworzenie w tych przypadkach korzystnych możliwości finansowych oraz wprowadzenie jasnych regulacji prawnych przyczyni się do przyjęcia przez rolników postawy aktywnego zarządzania ryzykiem działalności rolniczej, a tym samym do zwiększenia ich odporności na pojawiające się sytuacje kryzysowe. W przypadku „Przywracania potencjału produkcji rolnej zniszczonego w wyniku wystąpienia klęsk żywiołowych" narzędzie to nie wpływa istotnie na ochronę warsztatu producentów rolnych i wymaga zmian legislacyjnych. 


\title{
DURABILITY OF THE AGRICULTURAL PRODUCER'S WORKSHOP AS AN OBJECTIVE OF SUPPORT UNDER SELECTED ACTIVITIES OF THE RURAL DEVELOPMENT PROGRAMME 2014-2020
}

\begin{abstract}
Summary
The deliberations focus on the analysis of regulations included in the Rural Development Programme 2014-2020 concerning the instruments of support for investments that prevent destruction and restore the potential of agricultural production. They aim at answering the question whether and to what extent these forms of support protect the agricultural producer and ensure the durability of his workplace. The author argues, among other things, that two of them: "Investments aimed at protecting waters against nitrate pollution from agricultural sources" and "Support for investments in preventive measures aimed at reducing the effects of probable natural disasters, adverse climatic events and catastrophes," owing to favourable financing conditions and clear legal regulations introduced, contribute to an increased protection of farmers' interest by adopting specific attitudes towards active risk management in agricultural activity, and thus increase their resilience to emerging crisis situations. In the case of "Restoring the potential of agricultural production damaged by natural disasters" however, this tool does not significantly affect the protection of the agricultural producers' workplaces and requires legislative changes.
\end{abstract}

\section{PRESERVARE L'IMPRESA AGRARIA DEL PRODUTTORE AGRICOLO COME OBIETTIVO DI SOSTEGNO NELL'AMBITO DI ALCUNE MISURE SCELTE DEL PROGRAMMA DI SVILUPPO RURALE 2014-2020}

\author{
Riassunto
}

Le considerazioni svolte si concentrano sull'analisi della regolazione contenuta nel Programma di Sviluppo Rurale 2014-2020 in merito agli strumenti di sostegno a investimenti per la prevenzione e il ripristino del potenziale produttivo agricolo. L'obiettivo è di rispondere alla domanda se e in che misura i tipi di sostegno evocati tutelino il produttore agricolo e riescano a preservare l'impresa agraria. Nella parte conclusiva, l'Autore afferma, tra l'altro, che due di essi, ovvero "Investimenti effettuati al fine di proteggere le acque dall'inquinamento provocato da nitrati provenienti da fonti agricole" e "Sostegno agli investimenti in azioni di prevenzione volte a ridurre le conseguenze di probabili calamità naturali, avversità climatiche ed eventi catastrofici”, grazie ai finanziamenti a condizioni favorevoli e alle regolazioni giuridiche chiare, contribuiscono a far crescere l'interesse degli agricoltori ad adottare determinati atteggiamenti di fronte al problema di gestione attiva del rischio nell'attività agricola, aumentando così la loro resistenza alle situazioni di crisi. Nel caso di "Ripristino del potenziale produttivo agricolo danneggiato da calamità naturali", lo strumento non incide in modo significativo sulla tutela dell'impresa agraria dei produttori agricoli e richiede modifiche legislative. 